\title{
複数台首振りプロジェクタによる連続移動画像投影
}

\section{Displaying a Moving Image Using Multiple Steerable Projectors}

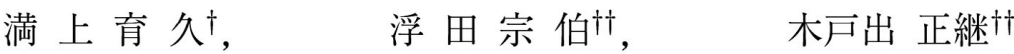

Ikuhisa Mitsugami ${ }^{\dagger}$, Norimichi Ukita ${ }^{\dagger \dagger}$ and Masatsugu Kidode ${ }^{\dagger \dagger}$

\begin{abstract}
We propose a method for precise overlapping of projected images using multiple steerable projectors. When steerable projectors are controlled simultaneously, two problems occur: (1) because the flatness of the projected planes is not suited to the real environment, each projected image from each multiple projector that is calibrated with just a part of the plane cannot always be located to the same position as that of an image from another projector, even when the images are intended to be located at the same position; and (2) because the projectors run asynchronously it is impossible to display a moving image by precisely tiling or overlaying the multiple projected images. To overcome this (1), we propose a method that preliminarily measures the misalignments through every plane in the environment, and hence displays the image without misalignment. For (2), we describe a method for the synchronization of moving and scaling between multiple projections.
\end{abstract}

キーワード : 首振りプロジェクタ, キャリブレーション, 歪み補正, 同期画像投影

\section{1. まえ がき}

プロジェクタを用いた実環境中への視覚情報表示技術は， 館内案内システム ${ }^{1)}$, 遠隔操作指示 ${ }^{2)}$, デザインシミュレー ション3) など多くのアプリケーションへの利用が提案され ている.ユーザがデバイスを身につける必要がなく, また実 環境の表面上に実際に画像を描くため見やすいというのが， これらの大きな利点である。これらのシステムでは, プロ ジェクタが固定設置されており，事前にその環境でキャリ ブレーションを行うことができるため，投影面に対して正 しい位置に画像を表示することができるが，投影できる範 囲は限られており，1）では特定の壁面や卓上, 2) や 3) では 静止した 3 次元物体上という，非常に限定された場所にし か画像表示を行うことができないという問題があった。こ の画像表示範囲の制約を克服する方法として，首振り機構 を持つプロジェクタを用いる方法や，曲面の鏡などを利用 してプロジェクタの画角を広げる方法が考えられるが, 前

IEEE International Workshop on Projector-Camera Systems で発表 2007 年 5 月 21 日受付, 2008 年 2 月 4 日最終受付, 2003 年 2 月 28 日採 録

†京都大学 学術情報メディアセンター

（干 606-8501 京都巾左京区吉田二本松町, TEL 075-753-9048)

††奈良先端科学技術大学院大学 情報科学研究科

（干 630-0192 奈良県生駒市高山町 8916-5,TEL 0743-72-5265)

$\dagger$ Academic Center for Computing and Media Studies, Kyoto University

(Yoshida-Nihonmatsu-cho, Sakyo-ku, Kyoto 606-8501, Japan)

$\dagger \dagger$ Graduate School of Information Science, Nara Institute of Science and Technology

(8916-5, Takayama, Ikoma, Nara 630-0192, Japan)
者はプロジェクタの構造が複雑になりキャリブレーション が不安定になるため表示位置の正確さを欠き，後者は空間 解像度が低下してしまうため上述のアプリケーションで用 いる局所的な画像表示には向かない.あるいは，固定のプ ロジェクタをアレイ状に並べる方法が考えられるが，これ はすべてのプロジェクタで同時に表示を行う場合以外には 無駄の多い構成であり，やはり上述のアプリケーションに は向かない.

そこで本論では, 6) で提案されている安定なキャリブレー ションが可能な首振りプロジェクタを利用し，さらにそれ らを環境の広さや形状に応じて複数台設置することによっ て，充分な解像度の画像を広範囲に表示可能なシステムを 構築する。なお，各首振りプロジェク夕の設置間隔をでき る限り大きくとると，効率的に広域化が可能であるし，ま た設置間隔を比較的小さくすると, 複数台のプロジェク夕 からの画像を重㸚わせて明るく表示したり，複数台から の画像を並べることで 1 台のプロジェクタでは表示できな い大きな画像を表示することも可能である.

このシステムにおいて，個々の首振りプロジェクタは 6) で示されたキャリブレーションによって環境中の平面上の 指定位置への画像表示が可能である。しかし，扱う投影平 面が広くなると，投影面全域に渡って完全な平面性を満た しているという前提は成り立たなくなる，その結果，各首 振りプロジェクタは，その投影光が届く範囲の局所的な平 面性に基づいたキャリブレーションを行うことになり, 複 数台のプロジェクタから同じ位置に投影したはずの画像は 正確には重なり合わず，わずかなズレが生じる。このズレ 
は，投影面のわずかな起伏によって生じ*，それらの起伏 は不規則に存在する。 そこで, 本論では, 投影面上に適当 な間隔で参照点を定め, それらの参照点に扔いてズレ量を 事前に観測することでズレ量に関するマップを用意し，オ ンライン実行洔に補正する手法を用いた。

また，連続的に移動・伸縮する画像を複数台のプロジェ クタによって表示する場合, 表示位置だけでなくその表示 時刻も合わせなければならないが, 非同期に動作する複数 台プロジェクタを個別に制御するだけでは表示時刻が一致 せず，結果的にズレた表示になってしまう，そこで本論で は, 複数台の非同期システムの統合手法として提案されて いるダイナミックメモリーアーキテクチャ5)をべースに， プロジェクタ入力画像算出時間も考慮に入れた, 複数投影 画像の表示位置変化・サイズ変化同期手法について提案し, その有効性を確認する.

\section{2. システム構成}

\section{1 投影中心固定型パンチルトプロジェクタ}

本論では, 首振りプロジェクタとして投影中心固定型パ ンチルトプロジェクタ (以下, FC-PT(Fixed-Center PanTilt) プロジェクタ) ${ }^{6)}$ を用いる. FC-PT プロジェクタは, その投影中心と回転機構の回転中心とが空間的に一致する ように設計された首振りプロジェクタである，首振りプロ ジェクタは，画角や焦点距離などといったプロジェクタの 投影光に関するパラメータだけでなく, 首振り雲台の構造 に関するパラメータを含む。 これらのパラメータすべてを 正確に推定するのは一般に困難であり, 正確で安定なキャ リブレーションを実現しにくい.これに対して, FC-PT プ ロジェク夕は, 姿勢が変化しても投影中心位置が変化しな い特殊な構造をとることで, 事前に推定すべき幾何学的な パラメー夕数が削減されているために, 正確・安定なキャ リブレーションを実現している。また, FC-PT プロジェク 夕を設置した際には，画像を表示したい複数の平面領域に ついて，プロジェク夕投影光の中心をその面の 4 隅に向け た際の角度を取得するのみで, プロジェクタと投影面の相 刘的な位置・姿勢が得られる. そのため, 投影面上のメ卜 リックな 2 次元座標系で画像の位置や大きさを与えれば, 向くべきプロジェクタのパン・チルト角，およびその姿勢 で投影面上に歪みなく画像が表示されるようにするために 逆変換された人力画像を算出できる。

\section{2 複数台プロジェクタ制御用の構成}

複数台の制御を考慮したシステム構成として, 複数台の プロジェクタをすべて 1 台の PCによって制御するものが 考えられる。この構成では，1台の PCがすべての情報の入 出力や制御を行うため, 複数台の制御が容易である. Yang

*㛜密には, 首振りプロジェクタ設置時のキャリブレーション誤差も, こ のズレの要因である.しかし，そのキャリブレーション誤差自体にも投 影面の非平面性が影響しており, この 2 種類の誤差要因を厳密に分離す ることはできない，そこで，本論では，これらの要因をまとめて扱って いる.

764 (132)

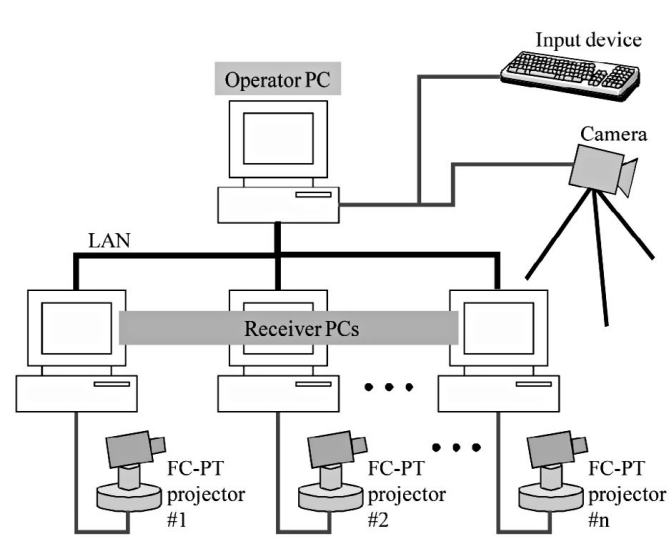

図 1 複数台プロジェクタ制御のための構成 Configuration for controlling multiple projectors.

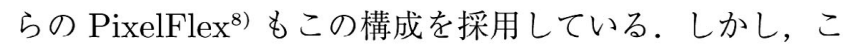
の構成はプロジェクタの台数に比例して PC の処理負担が 増し, スケーラビリティの面で問題がある.

そこで本論では，図１に示すように，プロジェクタ 1 台 につき PC (Receiver PC と呼ぶ) 1台を用意し，それらの $\mathrm{PC}$ 間をネットワークで接続する構成を採用する。各 Receiver PC は対応するプロジェクタの制御を受け持つ。さ らにネットワーク内には, これらの Receiver PC に投影 画像の位置や寸法などを指示する PC (Operator PC と呼 ぶ）を用意する．館内案内に利用する際の来訪者位置情報 や，表示画像を移動・伸縮させるキーボードやマウスなど の入力情報は，この Operator PCが受け付ける。 そして Operator PC は，それらの情報に応じた画像位置・寸法・ 角度情報（本論では，困像メトリックパラメータと呼ぶ）を ネットワークにブロードキャストし, 各 Receiver PCに伝 達する，本論では，投影する画像は静止画のみとし，使用 する画像は事前に各 Receiver PC に保存しておく。これに よって, 各プロジェクタは, 6)のキャリブレーション手法を 用いて，投影面上に設定したメトリックな 2 次元座標系に 対してキャリブレーションしておけば, Operator PCから 受け取る画像メトリックパラメータとプロジェクタの姿勢 制御や入力画像の生成が可能である. Operator PC は, 単 純にこの画像メトリックパラメータのみを各 Receiver PC にブロードキャストすればよい，この構成では，1台の PC に処理が集中することがないため，スケーラビリティの点 で優れており，建物の形状や広さに応じてプロジェク夕の 台数・配置を決めなければならない館内案内などのアプリ ケーションに適している.

\section{3. 複数静止投影画像の精密な重ね合わせ}

\section{1 ズレの発生要因とその対処策}

プロジェクタを用いて平面に画像を投影する研究では，プ ロジェクタの画像平面と実環境投影平面の間の Homography を利用することが多い 7)8 ．2.1節の FC-PT プロジェ クタも同様に平面上の 4 点から算出した Homography に よってキャリブレーションを行っている.この手法は, 投影 


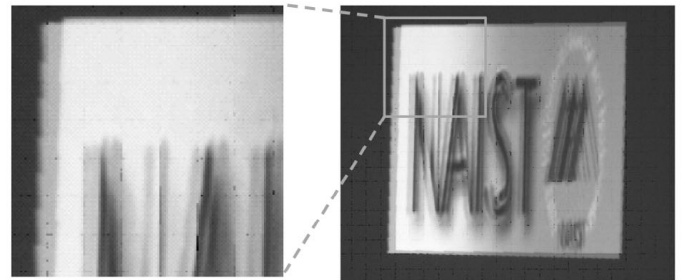

図 2 二つの投影画像間の位置ズレ

Misalignment of two projected images.

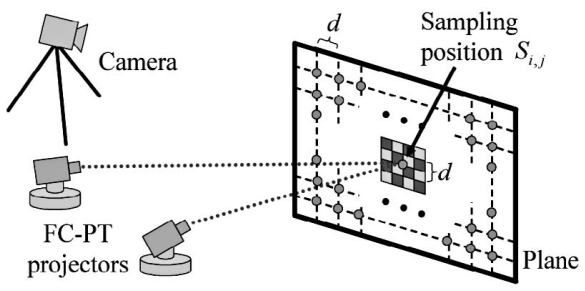

図 3 サンプリング位置への格子パターン投影

Grid pattern projection at a sampling position.

面の平面性に基づいているため，投影する領域が小さくそ の領域内で平面性が充分に満たされる場合には，正確な位 置への投影が可能である。しかし，本論で扱う広い投影面 の場合，投影面全域に渡って完全な平面性が満たされない ため，異なるプロジェクタから同じ位置に投影しようとし た画像間でわずかなズレが生じる．実世界の広い平面が完 全な平面性を満たすことはないため, 図 2 に示すように複 数の投影画像を重ね合わせようとしてもズレが生じ, ユー ザにとって見づらい表示となる。このズレは，投影面上に不 規則に存在するわずかな起伏によって生じるため, 事前の 位置ズレ観測は領域全体にわたって行わざるを得ない。そ こで本論では, 複数台のプロジェクタによって表示可能な 領域について，事前に投影画像間に生じるズレを観測しマッ プを作成しておき，実利用時にそのマップをもとに画像位 置を補正することで，ズレのない画像を表示する方法を採 用する．事前に行うズレ量の観測は，領域中に複数の観測 点に対して行うため作業時間を要するという欠点を持つが, この作業はプロジェクタ設置時にただ一度行えばよく，ま たカメラシステムと連携した自動化も可能なので，大きな 問題とはならない。

\section{2 ズレの観測とズレ量マップの生成}

投影面上に起伏は不規則に存在するため, 事前の位置ズ レ観測は領域全体にわたって密に行われなければならない が，明らかな起伏を含む面ではなく局所的に見れば充分な 平面性を満たす投影面を対象とするため，ある位置におけ る位置ズレはその周辺部における位置ズレと類似すると考 えても支障がない. よって，図 3 に示すように，投影面上 に㧤いて $i, j$ 方向にそれぞれ一定の間隔 $d$ でサンプリング 位置 $\boldsymbol{S}_{i, j}$ を定め, 各 $\boldsymbol{S}_{i, j}$ に対して, 各プロジェクタから その位置に投影を行うよう制御し，その結果表示された各 投影画像間の位置ズレ $\boldsymbol{v}_{i, j}$ を計測する。この $\left\{\boldsymbol{v}_{i, j}\right\}$ をズレ 量マップと定義する。

図4に，2台のプロジェクタを用いた場合に扔ける，各サ

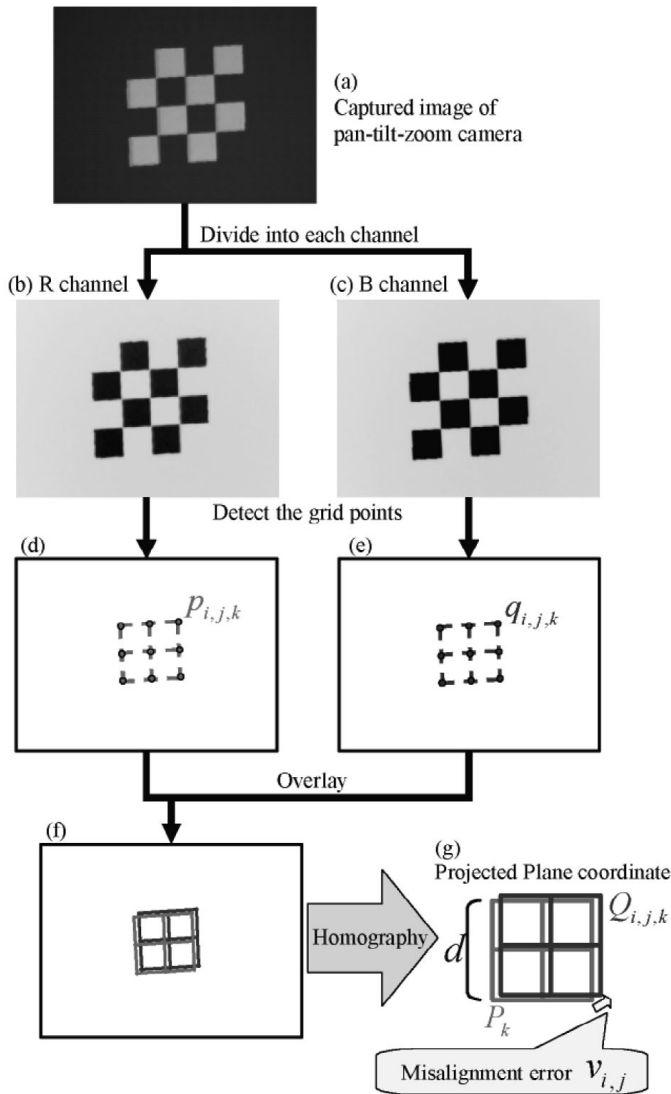

図 4 二つの投影パターン間のズレ量計測

Measuring a misalignment between two projected patterns.

ンプリング位置におけりる゙レ量計測処理の概要を示す．各 $\boldsymbol{S}_{i, j}$ に対して, 各 FC-PTプロジェクタをその位置に格子パ ターンを投影するように制御する。本論では，問隔 $d^{\prime}=d / 2$ の $4 \times 4$ 格子パターンを，その巾心の投影面上での座標が $\boldsymbol{S}_{i, j}$ となるように制御する。 それぞれのプロジェク夕から 投影された格子パターンは，投影面の非平面性のために真 の $\boldsymbol{S}_{i, j}$ からわずかにずれるため, 二つの格子パターンの間 には相対的なズレが生じる。一方のプロジェクタから赤色 のパターン，他方のプロジェクタから青色のパターンを用 いることにより，カメラで撮影した画像（図中 (a)）を色で 分離してこれらの格子パターンを別々に抽出することがで き(図中 (b)(c))，これらから，カメラ画像座標に抢ける 各格子点位㯰 $\boldsymbol{p}_{i, j, k}, \boldsymbol{q}_{i, j, k}(k=1, \cdots, 9)$ を計測する*（四 $4(\mathrm{~d})(\mathrm{e}))$. 次に, カメラ画像座標上で得られている $\boldsymbol{p}_{i, j, k}$ と $\boldsymbol{q}_{i, j, k}$ のズレを投影面上のメトリックな值に変換する。格 子パ夕ーンの間隔も，その投影位置と同様に投影面の非平 面性のためにわずかな誤差を持ちうるが，その誤差は非常 に小さいため，近似的に問隔は $d^{\prime}$ であるとみなすことがで きる．これにより， $\boldsymbol{p}_{i, j, k}$ と間隔 $d^{\prime}$ の格子点座標集合との 間に, 以下の平面射影変換式が成り立つ。

*電動首振りカメラを使うことでこの作業は自動化することも可能である. 首振りカメラによって，投影面上の絶対位置を観測しなければならない 場合は, 高精度なキャリブレーションが必要となるが, 本論の手法では, 複数投影パターン間の相対的な位置ズレの観湘のみ観測できれば上いの で, 投影パターンがカメラの画角内に扔さまる程度の姿勢制御を行うだ けでよく，容易に実現できる。 


$$
\left(\begin{array}{c}
P_{k}^{x} \\
P_{k}^{y} \\
1
\end{array}\right)=H_{i, j}\left(\begin{array}{c}
p_{i, j, k}^{x} \\
p_{i, j, k}^{y} \\
1
\end{array}\right)
$$

ただし， $H_{i, j}$ は $3 \times 3$ 行列であり，また $\boldsymbol{P}_{k}$ は投影面上の 格子点座標で, 次のように表される。

$$
\begin{array}{ccc}
\boldsymbol{P}_{1}=\left(-d^{\prime},-d^{\prime}\right) & \boldsymbol{P}_{2}=\left(0,-d^{\prime}\right) & \boldsymbol{P}_{3}=\left(d^{\prime},-d^{\prime}\right) \\
\boldsymbol{P}_{4}=\left(-d^{\prime}, 0\right) & \boldsymbol{P}_{5}=(0,0) & \boldsymbol{P}_{6}=\left(d^{\prime}, 0\right) \\
\boldsymbol{P}_{7}=\left(-d^{\prime}, d^{\prime}\right) & \boldsymbol{P}_{8}=\left(0, d^{\prime}\right) & \boldsymbol{P}_{9}=\left(d^{\prime}, d^{\prime}\right)
\end{array}
$$

$\boldsymbol{p}_{i, j, k}$ はカメラ観測により取得されているので, (1),(2) 式 より， $H_{i, j}$ が算出される. $\boldsymbol{p}_{i, j, k}, \boldsymbol{q}_{i, j, k}$ は同一の平面上に ある格子点とみなせるので, $\boldsymbol{Q}_{i, j, k}$ も次の式で求められる.

$$
\left(\begin{array}{c}
Q_{i, j, k}^{x} \\
Q_{i, j, k}^{y} \\
1
\end{array}\right)=H_{i, j}\left(\begin{array}{c}
q_{i, j, k}^{x} \\
q_{i, j, k}^{y} \\
1
\end{array}\right)
$$

ズレ量補正によって投影画像間のズレが悪化しないために は, 格子パターン間のズレ量計測誤差が, 投影面の非平面 性によるズレ量よりも充分に小さくなければならない，そ こで本論では, 対応する一組の格子点から算出するのでは なく, 次式のように九組すべての格子点のズレ量の平均を とることで, 格子パターン間のズレ量 $\boldsymbol{v}_{i, j}$ を安定して計測 できるようにしている.

$$
\boldsymbol{v}_{i, j}=\frac{1}{9} \sum_{k}\left(\boldsymbol{Q}_{i, j, k}-\boldsymbol{P}_{k}\right)
$$

\section{3 ズレ量マップを用いたズレ補正}

ズレ量マップ $\left\{\boldsymbol{v}_{i, j}\right\}$ が得られれば, 以後, 投影面上の任 意の位置 $T$ に扔けるズレ補正量 $u$ は，周辺サンプリング位 置におけるズレ $\boldsymbol{v}_{i, j}$ の線形補間で算出することができる.

$$
\begin{aligned}
\boldsymbol{u}= & \frac{(d-l)(d-m)}{d^{2}} \boldsymbol{v}_{i, j}+\frac{l(d-m)}{d^{2}} \boldsymbol{v}_{i+1, j} \\
& +\frac{(d-l) m}{d^{2}} \boldsymbol{v}_{i, j+1}+\frac{l m}{d^{2}} \boldsymbol{v}_{i+1, j+1}
\end{aligned}
$$

ただし $, i, j$ は以下を満たす最大の整数值である.

$$
\begin{aligned}
& T^{x}=S_{i, j}^{x}+l \quad(0 \leqq l<d) \\
& T^{y}=S_{i, j}^{y}+m \quad(0 \leqq m<d)
\end{aligned}
$$

ズレの補正方法としては，一方の投影画像を他方に合わせ るように移動させる方法と, 双方の投影画像を移動させる 方法が考えられるが, これら 2 投影画像の位置ズレは非常 に小さいため, どちらの方法を採っても構わない。ここで は, 一方の画像の処理を行っている Receiver PC 上の画像 メトリックパラメータの位置情報を $u$ だけずらすことで, 他方に合わせる。

このような位置合わせによって，一方あるいは両方の Receiver PC 上の画像位置情報を補正しているが，この補正 量は投影面の非平面性によって生じる位置誤差範囲内なの で，そもそもの各プロジェクタのキャリブレーション結果
を放棄するものではない，また，任意位置での $u$ はマップ の線形補間によって算出するため, 投影面上で滑らかに変 化する，そのため，後述する連続移動する画像表示の際に も，この補正によって画像移動が不自然になることがない のも利点である.

\section{4 サンプリング間隔の決定方法}

本論のシステムによって表示する画像の縦横の長さがサ ンプリング間隔 $d$ の倍であるとき，あるサンプリング位置 $\boldsymbol{S}_{i, j}$ が中心となるように画像を重㸚合わせた場合，その画 像の端が $\boldsymbol{S}_{i, j}$ の隣接サンプリング位置となる. そのため, 画像を $\boldsymbol{S}_{i, j}$ に扔けるズレ量 $\boldsymbol{v}_{i, j}$ を用いて補正しても，その 画像の端では, $\boldsymbol{S}_{i, j}$ とそ $\boldsymbol{S}_{i \pm 1, j \pm 1}$ におけるズレの量の差 $\Delta \boldsymbol{v}=\boldsymbol{v}_{i \pm 1, j \pm 1}-\boldsymbol{v}_{i, j}$ にほほ等しい* ズレが発生すること になる．また，本論で扱うようなほほ平面とみなすことの できる投影面の場合は, サンプリング間隔 $d$ が小さいほど $\Delta \boldsymbol{v}$ も小さくなると考元られる.

以上の関係より，サンプリング間隔 $d$ は，表示したい画 像サイズの半分以下を目安とする。これによって，画像を 重称合わせた際に実際に発生するであろうズレ量の最大值 を，観測した隣接サンプリング位置間におけるズレ量の差 の最大值 $\Delta \boldsymbol{v}_{\text {max }}$ によって推定することが可能となる．ま た， $\Delta \boldsymbol{v}_{\max }$ が $5 \mathrm{~mm}$ 以上の大きな值をとる場合には，サン プリング間隔 $d$ をっと小さくし，それに応じて表示する 画像のサイズも小さくしなけ狄ばならない，という判断を 行うこともできる.

また，本論の处理を行う上で. プロジェクタから罒 4(a) の格子パターンを投影し，カメラで観測できなければなら

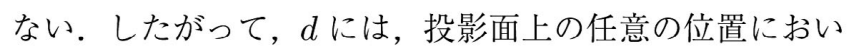
て $2 d \times 2 d$ の矩形がプロジェクタおよびカメラの画角内に おさまらなければならないという制約も存在する。

な押，本論のアプローチではサンプリング間隔 $d$ 内での 細かい起伏に対応することは原理的に不可能であるが，本 論では，3.2 節でも述べたように，画像が表示される局所 領域では充分な平面性が成り立つような投影面を前提とし ており，そのような細かい起伏に対する処理は行わない。

\section{5 投影結果と評価}

本論のズレ補正手法の有效性を確認するための実験を行つ た。具体的には，図 5 に示すように，FC-PT プロジェクタ （仕様は表 1）2 台と, パン・チルト・ズームカメラ 1 台（仕 様は表 2）を用いて，FC-PT プロジェクタから約 $2 \mathrm{~m}$ 前方 に $1200 \mathrm{~mm} \times 2400 \mathrm{~mm}$ の投影面を置いた.プロジェクタを 静止すると投影面上のおよそ $900 \mathrm{~mm} \times 1200 \mathrm{~mm}$ の領域に しか投影できないため，投影面全域に画像を表示するために は首振りが必要な環境である．投影面は $1200 \mathrm{~mm} \times 600 \mathrm{~mm}$ の平面四つを繋げた衝立を肉眼で観察して平面になるよう に広げたものを用いた。ズレ量マップ作成㫱のサンプリン グ位置の間隔は $200 \mathrm{~mm}$ とした.

\footnotetext{
*厳密には, プロジェクタ設置時のキャリブレーション䛊差の影響を受け るため，正確には一致しない． 


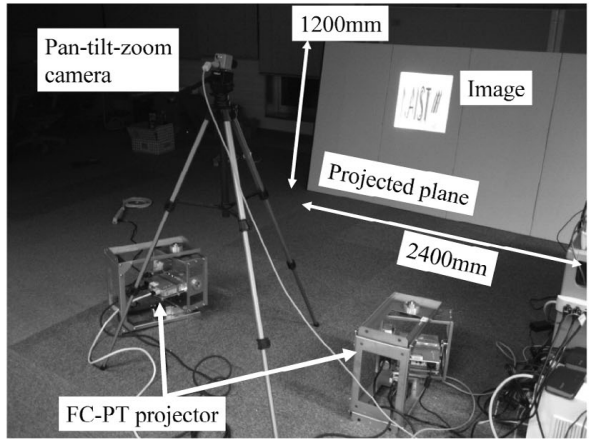

図 5 使用した環境

Experimental environment.

表 1 FC-PT プロジェクタの仕様

Specification of a FC-PT projector.

\begin{tabular}{|c|c|}
\hline \multicolumn{2}{|c|}{ プロジェクタ (PLUS VISION 社 V3-131) } \\
\hline 投映方式 & DLP \\
\hline コントラスト比 & 2000:1 \\
\hline 輝度 & $1000 \mathrm{~lm}$ \\
\hline 入力画像解像度 & $1024 \times 768$ \\
\hline \multicolumn{2}{|l|}{ 電動雲台 } \\
\hline 回転角精度 (パン, チルト) & $0.002 \mathrm{deg}$ \\
\hline 回転速度 & $10 \mathrm{deg} / \mathrm{s}$ \\
\hline 回転範囲 (パン) & $-60 \sim 60 \mathrm{deg}$ \\
\hline 回転範囲（チルト） & $-30 \sim 45 \mathrm{deg}$ \\
\hline
\end{tabular}

表 2 パン・チルト・ズームカメラ

Specification of a Pan-Tilt-Zoom camera.

\begin{tabular}{c|c}
\hline \hline \multicolumn{2}{c}{ カメラ (Pointgrey 社 Scorpion) } \\
\hline 画像解像度 & $800 \times 600$ \\
\hline 焦点距離 & $8 \sim 80 \mathrm{~mm}$ \\
\hline
\end{tabular}

電動雲台 (Directed Perception 社)

\begin{tabular}{l|l}
\hline 回転角精度 (パン・チルト) & $0.012857 \mathrm{deg}$ \\
\hline
\end{tabular}
回転速度
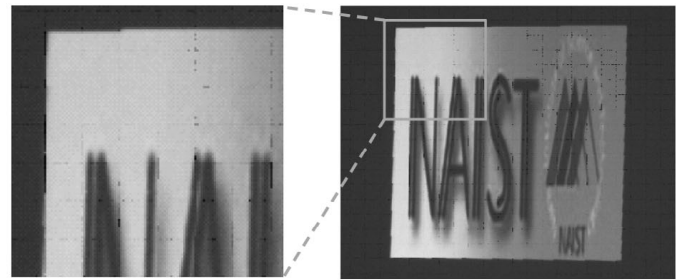

図 6 ズレ量マップを用いた位置ズレ補正結果 Image well-aligned by the misalignment map.

なお，補正後のズレ量マップ作成時のズレ量計測および 補正後の評価のためのズレ量計測は，3.2 節の図 4 に示す 方法で行った. 3.2 節で述べたように, 格子パターン中の 九つすべての格子点の平均でズレ量を計測しており, この 環境下での計測精度は約 $1 \mathrm{~mm}$ であった。投影画像間の補 正前のズレ量は最大 $10 \mathrm{~mm}$ であり，計測精度はそれと比較

\section{して充分に小さい}

実験の結果，投影面全域で，補正後のズレ量は $1 \mathrm{~mm}$ 以 下となった。これによって，図 2 に示した位置ズレが，図 6 のように補正された。このとき，筆者の肉眼による通常 の観測では，ズレは知覚できなかった.

また，複数台利用を活かした投影例についても確認した. 図 7 では，1台のプロジェクタでは投影しきれない大きな 画像を 2 台のプロジェクタで半分ずつ表示している例であ

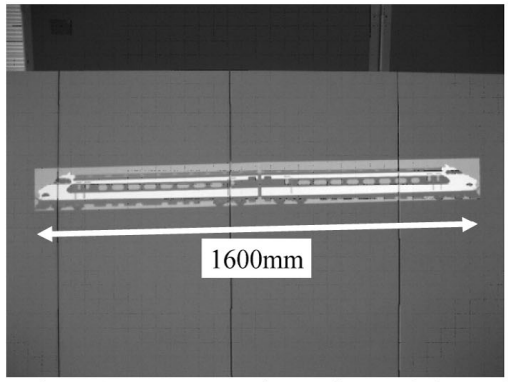

図 7 1 台のプロジェクタで表示できない大きな画像表示 Larger image projection by tiling multiple projections.

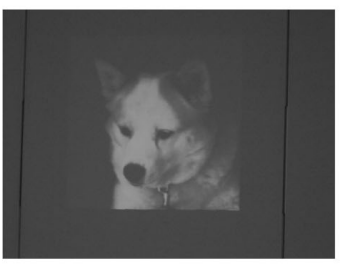

(a) 1 台による投影

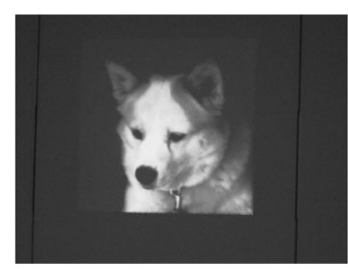

(b) 2 台による投影
図 8 投影画像の重ね合わせによる画像の高輝度化 Bright image obtained by overlaying multiple projections.

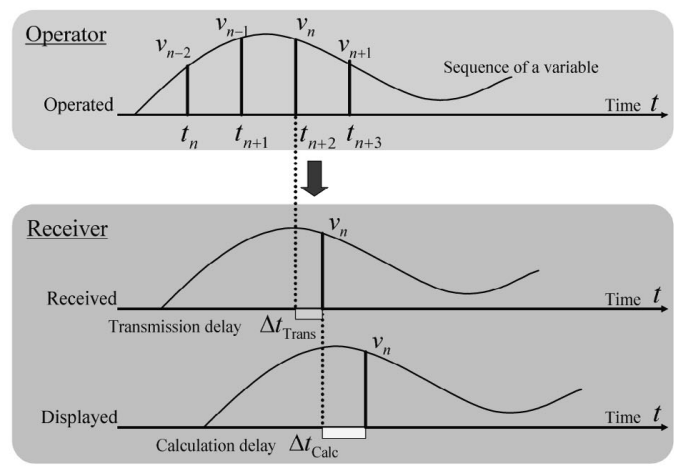

図 9 連続移動画像表示における問題 Problems in using multiple projectors.

る.プロジェクタの設置位置や視野角の制約上, 単体のプ ロジェクタでは $1200 \mathrm{~mm}$ 程度の幅の画像しか投影すること ができないが，2台の投影画像を横に並べ，その連結部で ズレのない自然な画像表示が実現できている。一方，図 8 では，2台のプロジェク夕の投影画像を重ね合わせること で画像の輝度を向上させた例である．2投影画像の重ね合 わせによって明るく，解像感が増した画像が得られること が確認できる。

\section{4. 複数台プロジェクタによる画像の移動・伸縮同期}

\section{1 複数台首振りプロジェクタの統合における問題}

表示する画像の位置・寸法が固定であれば， 3 章の手法 によって複数の投影画像の位置合わせを行うことができる. しかし，この重ね合わせた画像を人の動きに応じて連続的 に移動・伸縮するようなアプリケーションに利用する場合 には，新たな問題が生じる．システムは，図 1 に示した構 成のもとで, Operator PCから表示したい画像の位置や寸 法の時系列変化情報を標本化して送信するが，図 $9 *$ に示

\footnotetext{
*グラフの横軸は時間, 縦軸は画像メトリックパラメータの一つを表す.
} 


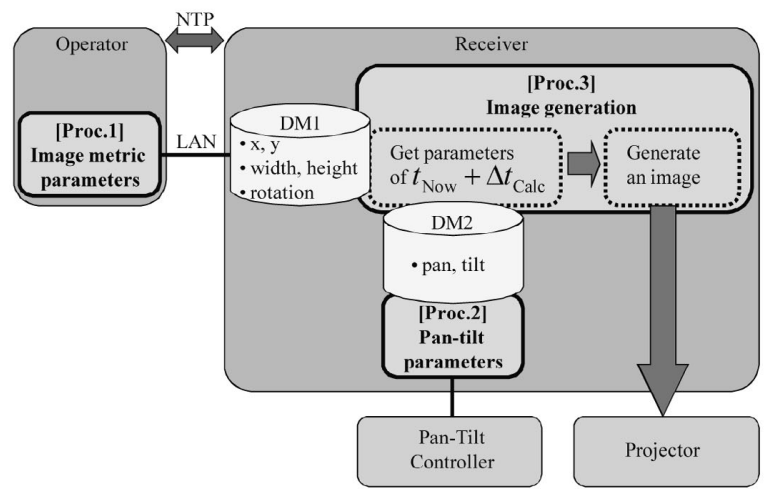

図 10 ダイナミックメモリーを用いた Receiver PC の処理 構造

Process of a Receiver PC using dynamic memory.

すように, Receiver PC がその情報を受け取るまでに伝送 遐延 $\left(\Delta t_{\text {Trans }}\right)$ を生じ，ささらに Receiver PC がその情報を 元にプロジェクタの入力画像を生成し実際に表示されるま でに演算遅延 $\left(\Delta t_{\text {Calc }}\right)$ を生じる。そして, これら二つの遅 延はネットワーク伝送路の長さや各 Receiver PC の処理久 ペックによって異なるため, 結果として各プロジェクタか ら表示されるタイミングが揃わず，投影画像間のズレとし て観測されるのである.

\section{2 複数画像の移動・伸縮の同期手法}

松山らが提案したダイナミックメモリーアーキテクチャ5) は，システム内で非同期に動作する複数のプロセス間の情 報共有方式である. 各プロセスがそれぞれ独立に最新のデー 夕を書込み参照する黒板型の情報共有ではなく, 書込みデー タにタイムスタンプを付けた履歴情報を保存しておく。デー 夕参照時には, 参照したい時刻を与えると, デー夕を履歷 情報の中からその時刻周辺のデータを選択し，それらの補 間計算によってその時刻のデー夕を算出する。この処理に よって，各プロセスは同期をとることなく，任意のタイミ ングで変数の読み書きを行うことができ, 複数の非同期プ ロセスを統合したリアルタイム処理が実現される。

図 10 に, 本論で提案した Receiver PCでの処理構造を 示す. Operator PCでは, 画像メトリックパラメータを送 信するプロセス (Proc.1) が実行される。一方, Receiver $\mathrm{PC}$ では, 首振り雲台からパン・チルト角情報を読取るプ ロセス（Proc.2）とプロジェクタの入力画像生成を行うプ ロセス（Proc.3）が害行される. 以上のプロセスはすべて 非同期で動作する。 そこで, Proc. 1 と Proc. 3 の間の情報 共有，および Proc. 2 と Proc. 3 の閭を統合したリアルタイ ム処理を実現するために，それぞれダイナミックメモリー DM1，DM2 を Receiver PC 上に設ける。ただし，DM1 については，異なる PC 内のプロセス間の情報共有である ため, 書込まれたデータの夕イムスタンプの時刻と, デー 夕参照の際に指定する時刻が異なる $\mathrm{PC}$ の時間軸によって 表現されるために，適切なプロセス統合がなされない。こ の問題は，それらの PC 間で NTPによって時刻同期をとっ

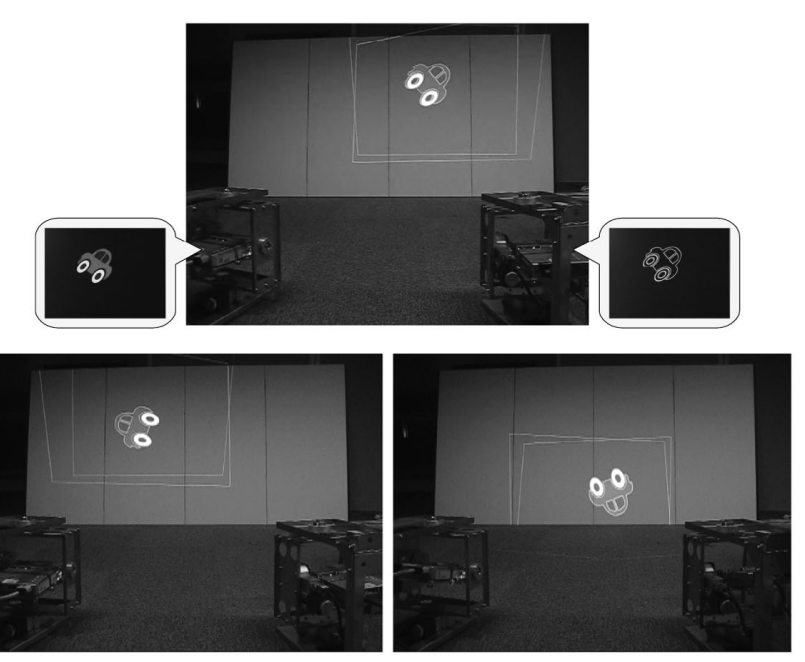

図 112 台の FC-PT プロジェクタを用いた連続移動画像投影 Moving image projection using two $\mathrm{FC}-\mathrm{PT}$ projectors.

ておくことによって解決される．時刻同期を取ることによっ て, ネットワーク伝送遅延はダイナミックメモリー内の補 間（予測）機能によって吸収され，同一PC 内プロセス間 のダイナミックメモリーと同様に動作する.

上記二つのダイナミックメモリーの導入により Receiver $\mathrm{PC}$ は任意の時刻の画像メトリックパラメータ抢よびパ ン・チルト角を取得できる。 そして, システムは現在時刻 $t_{\text {Now }}$ において, この時刻のパラメータではなく, ダイナ ミックメモリーの読込み時間*㧍よびその後のプロジェク 夕入力画像の生成処理に必要な時間 $\Delta t_{\text {Calc }}$ を加味した時 刻 $t_{\text {Disp }}=t_{\text {Now }}+\Delta t_{\text {Calc }}$ のパラメー夕を取得し, 入J画 像を算出して投影する。なお，正確には， $\Delta t_{\text {Calc }}$ は未知だ が, 入力画像は急激に変化することがないことから，その 生成処理にかかる時間も急激に変化しないものとし, 直前 フレームの生成処理に要した時間を用いる。

以上の処理によって, Operator PC と Receiver PC と の間の伝送遅延，および Receiver PC での演算遅延が解消 され, Operator PCが与えた移動・伸縮オペレーションに 同期して各プロジェクタから画像が投影される.

\section{3 評価実験}

本論では， 2 台の FC-PT プロジェクタを使用し，投影 実験を行った。実験環境は 3 章と同一とし，2 投影画像間 の位置合わせについても同様に行った. プロジェクタの首 振り制御については, コントローラ性能の制約から, 滑ら かな PID 制御ではなく, シンプルなストップアンドゴーの 制御を行った。

図11 は，2台の FC-PT プロジェクタからそれぞれ車の 画像㧍よびその輪郭線画像を同じ位置に投影し重㸚合わせ たまま，平面上を円軌道で移動させたときの動作の様子で ある。なお，図中の一っの四角形は，各FC-PT プロジェク

\footnotetext{
*本論の実装ではダイナミックメモリーでは，最新から 3 时刻分の履歴情 報から線形予測で指定時刻のパラメー夕算出をしている。 そのため，実 際にはこれにかかるオーバヘッドは，プロジェクタ入力画像の生成処理 に比べて極めて小さい.
} 


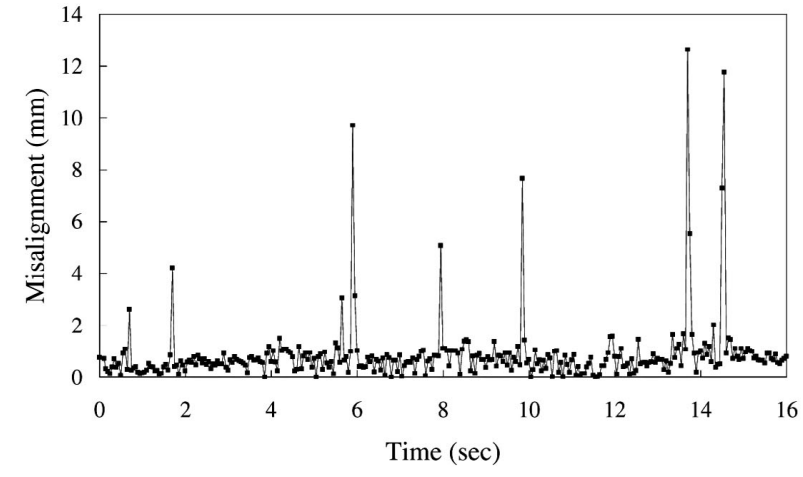

図 12 移動画像重ね合わせに抢ける位置ズレ観測結果 Misalignments when the image moves along a circle.

夕の投影可能な領域を示している. 実行した結果，2 画像が 重ね合わせによる画像であることが観察者には知覚できな い程度にズレは小さかった，また，Receiver PCにおける プロジェクタ入力画像生成处理は充分に速く (CPU Intel Xeon $3.2 \mathrm{GHz}$ ，メモリー2GB の PCで約 90fps), 各プロ ジェクタのフレームレートはその仕様の最大值である $60 \mathrm{fps}$ で動作しており，画像が滑らかに移動しているように観測 できた．また，Receiver PC の処理に待ち時間を挟むこと で，フレームレートを変更しながら観察したところ，筆者 は 20fps 以下では画像の移動の滑らかさが低下したと感じ た．滑らかな画像移動・仲縮を実現するには，30fps 以上の フレームレートが望ましい。

同じ条件で，投影困像間のズレに関する定量評価実験を 行った. ズレ計測は，3 章と同様に，格子パターンを投影し， それをカメラ観測することによって行った。ただし，プロ ジェクタのフレームレートが60fpsなのに対して, このカメ ラのレートは20fps のためすべての投影フレームが観測で きたわけではない，また，画像の移動速度は秒速 $100 \mathrm{~mm}$, $150 \mathrm{~mm}, 200 \mathrm{~mm}$ とした。秒速 $150 \mathrm{~mm}$ に扔ける計測結果 を図 12 に示す.グラフの横軸は時間, 縦軸は位置ズレの 大きさである. 全時間のうち $97 \%$ は位置ズレ量は約 $1 \mathrm{~mm}$ 以下という, 静止した画像でのズレ補正を行った 3.5 節と 同様の精度を示しており, やはり通常の観測で知覚不可能 であった（図 13(a)）。この結果は他の移動速度でも同様 である.

ただし，この実験の際に，図 13(b) のようにズレが大き くなる瞬間があった。これは図 12 のグラフでところどころ に見られるズレ量のピークに相当する。 これは, 首振り制 御は久トップアンドゴーの単純な制御であり, 画像の円運 動をプロジェクタの首振り運動によって追従する際に, パ ン・チルト回転が停止し, その後逆回転を始めるという動き をする*ため，ダイナミックメモリーに打けるパン・チルト 角の補間（予測）に瞬時的に失敗しているからである。こ

*例えば，画像が時計の 12 時の位置から 6 時の位置まで円運動する際に， パン運動はまず右に向かい, 2 時付近で停止し，4 時付近で左に回転を 再開する，という動きになる.

論 文 $\square$ 複数台首振りプロジェクタによる連続移動画像投影

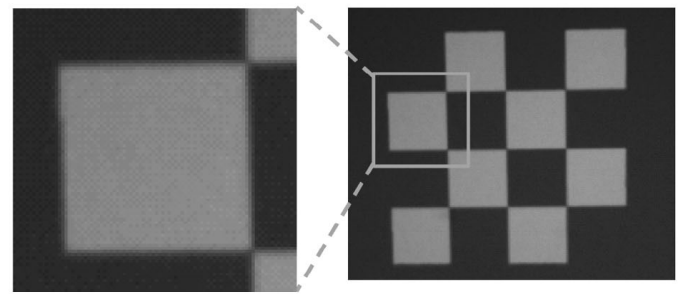

(a) 成功例

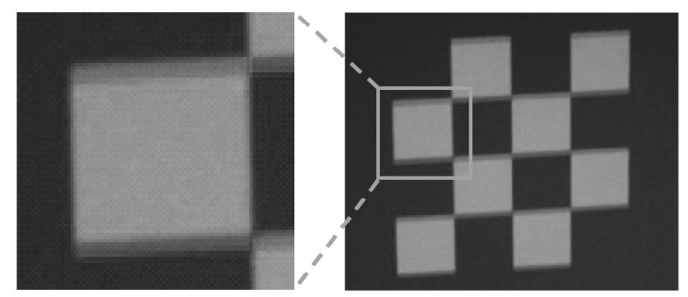

(b) 失敗例

図 13 移動画像の重ね合わせの成功例と失敗例 Examples of good/bad alignment results.

の瞬時的なズレは, 画像の移動速度（正確には，それに応 じて変化するプロジェクタの首振り速度）が大きいほど大 きくなるが，いずれも重权合わせが破綻して正しい画像と して見えない点は同じである．なお，この瞬時的なズレの 問題は，PID 制御によって滑らかな姿勢制御を実現するこ とで，軽減できると考えられる。

\section{5. むすび}

本論では, 複数台の首振りプロジェクタを環境中に配置 し，単に複数の画像を複数の位置に表示できるというだけ ではなく, 複数の投影画像を夕イル状に並べて大きな画像 を表示したり，同じ位置に重ね合わせることでより鮮明な 画像表示を行うことが可能な広範囲視営情報提示システム を提案した。首振りプロジェクタは, 固定式のプロジェクタ と比較して, 投影面上の広い範囲への画像投影が可能とな る点で優れている。しかし，実環境中の平面は広範囲に渡っ て完全な平面性を満たしていることは限らないため, 画像 投影を行う範囲が広がるほど，その平面性が信用できなく なる，すなわち，固定のプロジェクタであれば，その投影 範囲が小さいために，その投影範囲が完全な平面だと仮定 して画像投影を行っても問題ないのに対して, 首振りプロ ジェクタの場合は, 広い投影面全体を平面と仮定して画像 投影を行うと，その平面性に関する䛊差が無視できなくな り, 投影される画像にズレが生じてしまう。本論では，こ の位置ズレの問題を, 事前にズレ量を観測したマップを用 意しておくことで補正する手法を実装した。また，ダイナ ミックメモリーアーキテクチャを利用した複数台プロジェ ク夕間の投影画像の移動・伸縮の同期手法についても提案 した． 2 台の首振りプロジェクタを使って，重ね合わせた 投影画像を連続的に移動させる実験を行い, 提案手法の有 効性を確認した.

今後の課題として, 実環境中の平面以外の面への投影が 
考えられる.実環境中の床や壁などを投影面として利用す ることを考えると，本論で扱った平面だけではなく，円筒 状の柱など 1 方向のみに曲率を持つ曲面や，その他球面な どの任意形状曲面も存在する，本論のアプローチは，ズレ 量マップを利用することで完全な平面ではない面へのズレ のない投影を実現しているが，これは肉眼による観察で平 面だと判断される程度の面のみを想定しており, ズレ補正 の方法も画像の並進移動のみである。したがって, 肉眼に よる観察でも明らかな上述の曲面の場合には，本論のアプ ローチは適用できず，グレイコードパターン投影法 ${ }^{9)}$ など を用いて，その曲面の形状を計測しなければならない。た だし，円筒状の柱などについては，1 方向のみが曲率を持 ち，他方が直線であることを利用し，より容易な作業で投 影できる手法を検討したいと考えている.

別の課題として, 複数台プロジェク夕による動画像の重 ね合わせが挙げられる. 動画像を重ね合わせる場合, 表示す る動画像も同期しなければならないが，単に動画像情報を 同期して各 Receiver PC に入力する，あるいは各 Receiver PCで開始時刻を合わせて動画像ファイルを読込むという 処理だけでは，その後のプロジェクタ入力画像の生成処理 時間が Receiver PC 間で異なると実際に投影される動画像 は同期しない.この問題は, 動画像のフレーム番号も Operator PC-Receiver PC 間のダイナミックメモリーで取り 扱うことによって解決できると考えられる。ただし，その 場合でも, 各プロジェクタは非同期でフレーム更新を行う ため, 画像の更新夕イミングは $1 / 60$ 秒 (60fps のプロジェ ク夕の場合）の範讲でずれてしまう。この時間的なズレが 観察者に違和感を与えるものかは今後調査する必要がある と考えられる。逆に, Receiver PC 側のフレームレートが 極端に低い場合には, 表示される動画像にコマ落ちが発生 し，また長時間投影画像がロックされるために時間的にず れたフレームが重なり合うことになるので，重㸚合わせた 画像に違和感が生じると思われる。しかし，それほどまで 遅いレートでは，そもそも画像の移動・伸縮自体がなめら かでなくなってしまう. 4.3 節で述べたように, 動画像を 扱う場合でも, Receiver PC は 30fps 程度のフレームレー 卜を維持できるよう実装すべきである。

また，連続移動する 3 次元形状物体への投影システムの 構築にも取り組みたいと考えている。このシステムでは, プ ロジェクタの投影中心位置が不変なため, 物体の位置·姿勢 を与えれば各プロジェクタの姿勢とは無関係に投影しうる 物体表面領域が一意に定まるという, FC-PT プロジェク夕 の特徵を有効に活かすことができる。すなわち, 入力画像 算出にその時刻の姿勢情報を取得する必要がないため, 高 フレームレートで遅延の少ない表示が期待できる。このよ うなシステムに扔ける, 物体の位置・姿勢の高精度リアル 夕イム計測，物体表面に投影不可能な領域が生じないよう なプロジェク夕配置, 物体表面の明度差の抑制や相互反射 の考慮などといった光学的問題が, 今後の課題であると考
えられる.ささらに, システム大規模化への対策として，ネッ トワークの階層化や分散協調システムなども検討課題とし て考えられる。

\section{〔文献〕}

1) Claudio Pinhanez, Rick Kjeldsen, Anthony Levas, Gopal Pingali, Mark Podlaseck, and Noi Sukaviriya: "Applications of steerable projector-camera systems", In Proc. International Workshop on Projector-Camera Systems (ProCams2003), IEEE Computer Society Press (2003)

2）東城賢司，日浦慎作，井口征士：“プロジェクタを用いた 3 次元遠隔指 示インタフェースの構築”，日本バーチャルリアリティ学会論文集，7, pp.169-176 (2002)

3) Ramesh Raskar, Greg Welch, Kok-Lim Low, and Deepak Bandyopadhyay: "Shader lamps: Animating real objects with image based illumination", In Proc. 12th Eurographics Workshop on Rendering Workshop, pp.89-102 (2001)

4) Mark Ashdown, Yoichi Sato: "Steerable projector calibration", In Proc. International Workshop on Projector-Camera Systems (ProCams2005). IEEE Computer Society Press (2005)

5) Takashi Matsuyama, Shinsaku Hiura, Toshikazu Wada, Kentaro Murase, Akio Yoshioka: "Dynamic Memory: Architecture for Real Time Integration of Visual Perception, Camera Action, and Network Communication", In Proc. IEEE Computer Society Conference on Computer Vision and Pattern Recognition (CVPR2000), 02, pp.728-735, IEEE Computer Society (2000)

6）満上育久, 浮田宗伯, 木戸出正継: “投影中心田定型パンチルトプロジェク タとキャリブレーション”, 信学論 D, J90-D, 11, pp.3065-3078 (2007)

7) Takayuki Okatani, Koichiro Deguchi: "Autocalibration of an ad hoc construction of multi-projector displays", In Proc. International Workshop on Projector-Camera Systems (ProCams2006), IEEE Computer Society Press (2006)

8) Ruigang Yang, David Gotz, Justin Hensley, Herman Towles, Michael S. Brown: "Pixelflex: a reconfigurable multi-projector display system", In Proc. the conference on Visualization '01, pp.167-174, IEEE Computer Society (2001)

9）井口征士，佐藤宏介： “三次元画像計測”, 昭晃堂, pp.80-91 (1990)

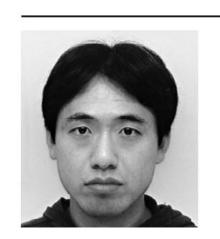

満上が 妄咅久 2001 年, 京都大学工学部電気電子工 学科卒業. 2007 年, 奈良先端科学技術大学院大学情報科 学研究科博士後期課程修了. 同年, 京都大学学術情報メ ディアセンター研究員 (科学技術振興).コンピュータ ビジョン, 対象抽出・追跡, プロジェクタによる実環境 視覚情報提示に関する研究に従事. 博士 (工学).

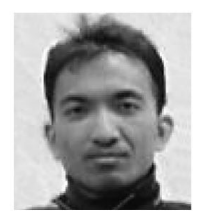

浮田 宗伯 2001 年, 京都大学大学院博士後期課 程修了. 同年, 奈良先端科学技術大学院大学情報科学研究 科助手. 2007 年同准教授. 2002 年〜 2006 年まで, 科学 技術振興機構さきがけ研究員兼任. 現在, カーネギーメ ロン大学客員研究員兼任. 博士 (情報学). コンピュー夕 ビジョン, 分散協調視覚, 対象追跡に関する研究に従事.

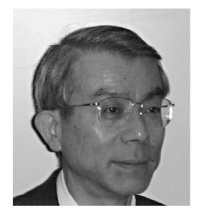

木杢户出帮さ継 1970 年, 京都大学大学院修了. 同年, 東京芝浦電気 (現，東芝) 総合研究所入社. 東芝アメリ 力社を経て，2001 年, 奈良先端科学技術大学院大学教 授. 京都大学工学博士. パターン認識, コンピュータビ ジョンに関す吕研究に従事. 